\title{
Overview of outcomes of project Didaktika - Člověk a príroda A (Didactics - Human and Nature A)
}

Cite as: AIP Conference Proceedings 2152, 030023 (2019); https://doi.org/10.1063/1.5124767 Published Online: 05 September 2019

Pavel Masopust, Jiří Kohout, Marie Mollerová, and Lukáš Feřt

\section{ARTICLES YOU MAY BE INTERESTED IN}

Formation of the natural-science image of the world in early years education AIP Conference Proceedings 2152, 030008 (2019); https://doi.org/10.1063/1.5124752

Interactive show physics through all senses

AIP Conference Proceedings 2152, 030021 (2019); https://doi.org/10.1063/1.5124765

Physics experiment as a dominant educational element

AIP Conference Proceedings 2152, 030024 (2019); https://doi.org/10.1063/1.5124768

Lock-in Amplifiers Find out more today

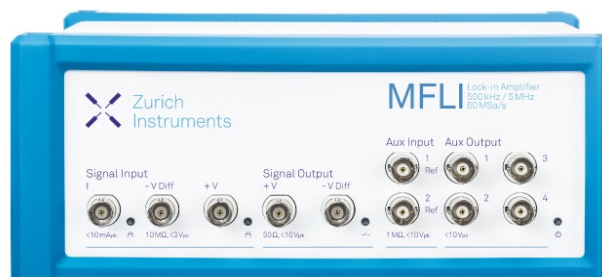




\title{
Overview of Outcomes of Project Didaktika - Člověk a př́roda A (Didactics - Human and Nature A)
}

\author{
Pavel Masopust ${ }^{1, a)}$, Jiř́i Kohout ${ }^{1, b)}$, Marie Mollerová ${ }^{1, c)}$, and Lukáš Feřt ${ }^{1, d)}$ \\ ${ }^{1}$ University of West Bohemia in Pilsen, Klatovská 51, 30614 Pilsen, Czech Republic \\ a)Corresponding author: pmasop@kmt.zcu.cz \\ b)jkohout4@kmt.zcu.cz \\ c)maruska@cbg.zcu.cz \\ d)1fert@cbg.zcu.cz
}

\begin{abstract}
Aim of described research is (was) to determine and suggest how to remove critical spots in lower-secondary physics curriculum. As critical spots we understand the problems with the physics concepts during learning and teaching. We used a multicriterial approach and analyzed basic curricular documents, TIMSS results and carried out a survey with 31 teachers of physics. We found six critical spots of curriculum of physics education and tried to find out if the criticality may be explained by psychodidactic and ontodidactic theory. Consequently, we prepared educational modules that addressed these six spots and currently we are verifying their effectivity.
\end{abstract}

\section{INTRODUCTION}

In previous years no special attention was paid to critical spots in physics education. Similar problems were studied in the field of math education both abroad [1] and in the Czech Republic too [2-4].

In 2017 we participated in project "Didaktika - Člověk a príroda A" (Didactics - Human and Nature A) that tries to address directly this area of physics education (other teams of this projects work on critical spots of geography, biology and chemistry). Our research focuses on first two years of physics education - lower secondary physics curriculum. First, we prepared theoretical and methodological fundament which evolved from foundations of instrumental realism and conceptual physics and hierarchize physics education concepts. We distinguished between key, substantive, organizational and applicational concepts [5-7].

Critical spots then can be understood as problems with concepts instrumentalization [8]. We believe that described problems can be solved (by changing curriculum, new modern approaches to critical spots...). For further information on this hierarchy see our previous papers [5-7]. Main aims of our work were (or is as the research is not currently spring 2019 - finished):

1. Find critical spots in lower-secondary physics education. Use more methods and validate the results.

2. Find if these spots are caused by lack of math knowledge.

3. Use research outcomes and design new educational material (modules) that will help teachers overcome critical spots.

\section{LOOKING FOR CRITICAL SPOTS}

\section{Survey}

How we tried to find the critical spots? We believe that only one method would not be sufficient, so we used more approaches. 
Firstly (and perhaps mainly) we conducted the survey with 31 experienced teachers of physics. We had four particular research questions:

1. What topics of lower-secondary physics education do you consider critical?

2. How would you describe critical spot?

3. How math influences the critical spots of physics education?

4. How do you deal with critical spots yourself?

With these four questions in mind we designed semi-structured questionnaire and got results from 31 experienced teachers of physics.

First, we recorded the interviews conducted by our team members. Interviews were 31 minutes length in average. In the middle of the interview participants were given list of 80 lower-secondary physics education topics and were asked to select 10 they consider critical. At the end, they repeated this procedure but now without considering mathdifficulties of each topic.

We transcribed sound records to text and carried out the content analysis in software ATLAS.ti. We got a tree visualization of our concepts and selected critical spots. Quantitative analysis was applied too.

\section{Our Participants}

We worked with 31 experienced (they taught physics 13 years in average) lower-secondary teachers of physics 14 males and 17 females. They were not only from West Bohemia part of Czech Republic but also from other regions (7 from Ústecký, 5 from Olomoucký, Královéhradecký, Plzeňský, 3 from Jihočeský and Pardubický). We haven't had teachers from Prague, Karlovarský, Vysočina and Moravskoslezský region.

We see in the Fig. 1 that the consideration of math affected the choices. More qualitative topics (lenses, field lines) were not affected much, some other were (density, charts).

In the next part of interview, the teachers were asked why they selected the given topics and why they considered them critical.

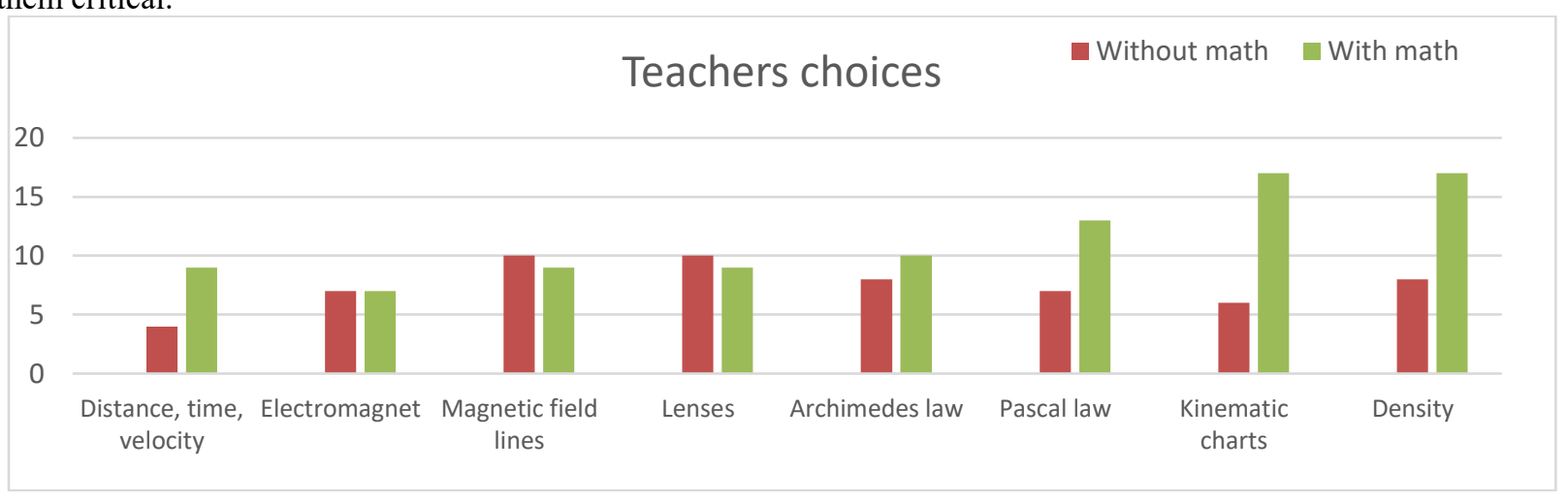

FIGURE 1. Critical spots from physics teacher survey.

\section{TIMSS}

TIMSS stands for "Trends in International Mathematics and Science Study". Detailed information can be found in our previous study [7]. We tried to find critical spots analyzing results of TIMSS and compare these findings with spots found in the interviews with teachers.

We spotted 19 main problematic tasks with results of Czech pupils much lower than international average. We compared just Czech Republic, England, Slovenia, Slovakia and Finland results. 
TABLE 1. TIMSS Czech and international pupil average achievements - percentage of correct answers

\begin{tabular}{|c|c|c|c|}
\hline Concept & $\begin{array}{c}\text { Average } \\
\text { Czech/International }\end{array}$ & Best average & $\begin{array}{c}\text { TIMSS } \\
\text { Identification/Year }\end{array}$ \\
\hline $\begin{array}{l}\text { 1. Electromagnet } \\
\text { (applicational concept) }\end{array}$ & $22.0 / 36.9$ & 55.9 (England) & S032273/2007 \\
\hline $\begin{array}{l}\text { 2. Magnetic poles, magnetic field lines } \\
\text { (organizational concept) }\end{array}$ & $39.6 / 49.1$ & 54.4 (Slovenia) & S022035/1999 \\
\hline $\begin{array}{l}\text { 3. Energy transformation (organizational } \\
\text { concept) }\end{array}$ & $26.8 / 34.9$ & 60.7 (England) & S032024/2007 \\
\hline 4. Energy (substantive concept) & $18 / 24.5$ & 41.8 (England) & S012047/1999 \\
\hline $\begin{array}{l}\text { 5. Energy transformation (organizational } \\
\text { concept) }\end{array}$ & $\begin{array}{l}57.1 / 58.3 \\
(y .1995) \\
54.6 / 58.7 \\
(y .1999)\end{array}$ & 76 (England, 1995) & S012022/1995,1999 \\
\hline $\begin{array}{l}\text { 6. Propagation of light (organizational } \\
\text { concept) }\end{array}$ & $34.5 / 46.7$ & 65.4 (England) & Q12/1995 \\
\hline $\begin{array}{l}\text { 7. Application of electric circuits } \\
\text { (application concept) }\end{array}$ & $16.1 / 17.5$ & 38.1 (England) & S042196/2007 \\
\hline $\begin{array}{c}\text { 8. Phase changes (organizational } \\
\text { concept), mass (substantive concept) }\end{array}$ & $37.2 / 43.2$ & 48.2 (Slovakia) & S042173B/2007 \\
\hline 9. States of matter (substantive concept) & $40.1 / 40.8$ & 61.6 (England) & S032403/2007 \\
\hline $\begin{array}{l}\text { 10. Thermal dilatation (organizational } \\
\text { concept) }\end{array}$ & $34.0 / 36.2$ & 54 (England) & S042061/2007 \\
\hline 11. Density (substantive concept) & $28.3 / 29.4$ & 46.4 (England) & S012009/1999 \\
\hline $\begin{array}{c}12 . \\
\text { concept) }\end{array}$ & $32.9 / 25.8$ & 48.7 (Finland) & S022048/1999 \\
\hline $\begin{array}{c}\text { 13. Solidification } \\
\text { concept) }\end{array}$ & $54.1 / 39.7$ & 72.8 (Slovakia) & S022268/1999 \\
\hline 14. Efficiency (organizational concept) & $29.7 / 30.7$ & 50.4(Slovakia) & S022017/1999 \\
\hline $\begin{array}{l}\text { 15. Propagation of light (organizational } \\
\text { concept) }\end{array}$ & $22.9 / 24$ & 32.4 (Slovakia) & S022043/1999 \\
\hline $\begin{array}{l}\text { 16. Shadows, umbra and penumbra } \\
\text { (organizational concept) }\end{array}$ & $\begin{array}{l}59.4 / 59.2 \\
(\text { y. 1995) } \\
55.9 / 59.6 \\
\text { (у. 1999) }\end{array}$ & 62.3 (Finland, 1999) & S012029/1995,1999 \\
\hline $\begin{array}{l}\text { 17. Propagation of light (organizational } \\
\text { concept) }\end{array}$ & $69.4 / 69.5$ & 81.9 (Slovenia) & S012004/1995 \\
\hline 18. Air (substantive concept) & $26.1 / 33.1$ & 34.9 (England) & K10/1995 \\
\hline 19. Lever (application concept) & 20.6/19.1 & 39.6 (England) & S042244A/2007 \\
\hline
\end{tabular}

As we see, greatest gap between Czech pupils and international average is in the case of concept of Electromagnet (question was what will happen with nail winded with wire connected to the battery).

Second biggest difference was with question 2. - magnetic poles and field lines (question Label magnetic poles on halved permanent magnet).

We also estimated (based on analysis of curricular documents and interviews with teachers) why these concepts or tasks were problematic:

- Optics, electromagnets, magnets are topic mainly introduced at the end of school year and there is not enough time for detailed explanations.

- Some tasks were uncommon for Czech schoolbooks (mainly concept Light propagation). Some problems can be seen as too simple for teacher to explain them to pupils at all. These "obvious" tasks can then be difficult for pupils. 
Generally problematic tasks are to be found in all parts of lower-secondary physics education. Are not limited just for, for example, mechanics, electricity or optics. Causes of criticality need to be searched for from both ontodidactic and psychodidactic point of view and are typical for each individual task. International researches are source of valuable information regarding critical spots of physics education.

\section{Analysis of Czech School Inspectorate Results}

We deeply analyzed results of Czech school inspectorate research. This research has been conducted in years 2016/2017. Research includes almost 6000 pupils of age 15 (secondary school) and around 13000 pupils of age 18 (high school) [9]. We can see some inspiration taken from PISA research. Tasks are therefore focused on scientific thinking in general, not limited to one subject (physics, chemistry...). This research is not eligible for critical spots findings, as is more focused on general abilities rather than on specific topics.

Nevertheless, some conclusions are clear:

- Students that stated that physics is important for task solving achieved higher scores than those who didn't. Thus "physics thinking" was important. This was not case of other subjects (chemistry, biology...).

- Pupils have problems with physics experiments interpretation. They are mostly not able to describe what was experiment designed for and what can be concluded from it.

- There are multiple problems with graphs reading. Students confuse axes, read wrong values etc.

\section{FOUNDED CRITICAL SPOTS}

Our task was to identify critical spots with combination of the results of TIMSS, teachers survey and analysis of Czech school inspectoral research. Most valuable were results from interviews with teachers. By combining all gathered evidence, we determined these critical spots:

- Magnetic properties of electric current and electromagnet

- Magnetic field and field lines

- Density

- Lenses

- Hydrostatic pressure and Archimedes law

- Pascal law and hydraulic equipment

Similar results were found by our colleagues in science centers research - IQLandia in Liberec and World of Technics in Ostrava. They found last two spots as the most critical.

\section{NEW EDUCATIONAL MATERIALS - MODULES}

We designed new educational materials from scratch. We didn't want to write new schoolbooks or prepare new material for whole lower-secondary physics.

Rather we focused on most critical parts of each critical spot. We prepared first module, have series of discussion with teachers, modified the material etc. They recommended to build the modules from basic elements - experiment, task, question.

We also didn't want to "prescribe" how to put these elements together. We presented basic elements as part of LMS Moodle and let teacher to piece them together. Currently we are waiting for reflection and suggestions from teachers.

Video experiments are main element of our modules. Teachers often does not have time to prepare experiments, or they have no proper equipment or measure devices. Our video experiments can be played in classes and discussed with pupils, or they can serve as "handbook" for teacher showing them how to prepare the experiments. That is better of course. If the teacher has enough of time and equipment, the experiment can be carried out even by pupils, which would be probably the best solution.

We haven't included test questions or tasks where pupils should count or derive something. These parts are sufficiently covered in other sources (internet collections of physics tasks, prepared exams etc.) 


\section{CONCLUSION}

Our research has some "known" limitations. We didn't analyze pupils work, or asked them which topics they consider critical. This may be task for another research.

Probably we also haven't found some critical spots as teacher don't see them as critical. Students can have good results in some tasks, but the conceptual understanding may absent. Teacher will not find out as they use only methods, that not reveal such task as critical. This is common problem of validity of educational tasks/tests (it is known issue not only in physics education).

For example, considering results of Force concept inventory one can expect that we shall find Newton laws or force as critical spot in physics education [10]. TIMSS questions were not focused on this part of physics and they were not mentioned in our interviews neither. We haven't therefore stated force or Newton laws as critical spots. Based on our results we are entitled to say that our critical spots are certainly critical, but we cannot argue, that these are the only critical spots in lower-secondary physics education.

Aim of this article was to briefly present our research. Detailed information and more in-depth explanations are to be found in articles and papers in references.

\section{ACKNOWLEDGMENTS}

Our research is funded from OP VVV Didaktika - Člověk a př́roda A (CZ.02.3.68/0.0/0.0/16 011/0000665).

We thank the teachers who participated in our survey and interviews.

\section{REFERENCES}

1. Texas Education Agency, Texas Response to Curriculum Focal Points Revised 2013 (Austin, Texas education Agency, 2013) Available online: https://www.texasgateway.org/sites/default/files/resources/documents/TXRCFPrevised2013.pdf.

2. M. Rendl, N. Vondrová, L. Hříbková, D. Jirotková, J. Kloboučková, L. Kvasz and J. Žalská, Kritická mista matematiky na základni škole očima učitelů (Praha, Univerzita Karlova, 2013).

3. M. Rendl and N. Vondrová, Pedagogická orientace 24(1), 22-57 (2014).

4. N. Vondrová et al., Kritická místa matematiky základní školy v řešeních žáků (Praha, Univerzita Karlova, 2017).

5. P. Mentlík, J. Slavík and J. Coufalová, Arnica 8(1), 9-18 (2018).

6. J. Kohout, M. Mollerová, P. Masopust, L. Feřt, O. Kéhar and J. Slavík, Arnica 8(1), 26-34 (2018).

7. J. Kohout, M. Mollerová, P. Masopust, L. Feřt and J. Slavík, Pedagogická orientace 29(1), 5-42 (2019).

8. L. Kvasz, Inštrumentálny realimus (Červený Kostelec, Pavel Mervart, 2015).

9. ČŠI, Rozvoj prírodovědné gramotnosti na základnich a střednich školách ve školním roce 2016/2017 (Praha, Česká školní inspekce, 2018) Available online: https://www.csicr.cz/getattachment/cz/Dokumenty/Tematickezpravy/Tematicka-zprava-\%E2\%80\%93-Rozvoj-prirodovedne-gramotnosti/Rozvoj-prirodovednegramotnosti.pdf.

10. D.Hestenes, M. Wells and G. Swackhamer, The physics teacher 30(3): 141-158 (1992). 